\title{
Zooplankton variation in Fraijanes Lake (Costa Rica) during the course of one year
}

Gerardo Umaña-Villalobos ${ }^{1,2 *}$, Lidia Avilés-Vargas ${ }^{1,2} \&$ Octavio Esquivel-Garrote ${ }^{3}$

1. Escuela de Biología, Universidad de Costa Rica, San Pedro, San José 2060, Costa Rica; gerardo.umana@ucr.ac.cr; lidiav804@gmail.com

2. Centro de Investigación en Ciencias del Mar y Limnología (CIMAR), Ciudad de la Investigación, Universidad de Costa Rica, San Pedro, San José 2060, Costa Rica

3. Instituto de Oceanografia, Universidade Federal de Rio Grande, Campus Carreiros, Avenida Itália km 8, Rio Grande do Sul, Brasil; octageo@gmail.com

* Correspondence

Received 16-I-2017. Corrected 30-XI-2017. Accepted 03-I-2018.

\begin{abstract}
Zooplankton in small tropical lakes has been little studied and its variation during the year may respond to different factors. In this study, the zooplankton of a small neotropical lake was studied at different times during one year and compared with changes in the lake conditions and in phytoplankton composition. The lake stratifies from March until September, and mixes during the hemispherical winter, from October until February. Besides the lake show a seasonal fluctuation in water level according to the seasonality of rains. Zooplankton was composed of at least 13 species, four Cladocerans, three Copepods, four Rotifers and other groups such as an Ostracod and the larvae of Chaoborus. The most abundant were Thermocyclops sp., Daphnia sp. and Keratella tropica. Their abundance fluctuated along the year, probably in response to changes in lake level and changes in hydrological conditions, increasing during dry season when the main outlet of the lake dried up. Changes in phytoplankton composition do not seem to be as relevant for zooplankton variation in this small lake. Rev. Biol. Trop. 66(Suppl. 1): S123-S131. Epub 2018 April 01.
\end{abstract}

Key words: Zooplankton, Neotropics, small lake, seasonality.

Zooplankton is an important component of all water bodies, from small ponds to large lakes. Its seasonal variability has been described for temperate lakes and summarized in the model developed by the Plankton Ecology Group (PEG) (Sommer, Gliwicz, Lampert, \& Duncan, 1986; Sommer et al., 2012). Their model explains planktonic seasonality as the result of a combination of factors associated with temperature, food availability and quality and predation pressure. According to this model, tropical conditions are similar to summer conditions of temperate regions that prevail all year round. In temperate lakes, summer time temperature increases, so a direct stratification occurs. Surface nutrients are consumed rapidly and lake productivity decreases later in the season (Hutchinson \& Löffler, 1956; Sommer et al., 1986; Roldán- Pérez \& RamírezRestrepo, 2008). However, in tropical regions the driving role played by seasonal variation of temperature and light availability is reduced (Lewis, 1996). It means that species interactions of predation and competition are active all year round, without the starting point in plankton succession that is common to occur during spring at temperate lakes. The main driving force for seasonal changes in tropical ecosystems is usually the variability of precipitation associated to the migration of the Intertropical Convergence Zone (ITCZ) (Kricher, 2011; Haug, Hughen, Sigman, Peterson, \& 
Röhl, 2001; Waylen, Caviedes, Poveda, Mesa, \& Quesada, 1998, De Groot, 1998). Studies on seasonal changes of lacustrine zooplankton composition in tropical regions had yielded different results and vary depending on the system (Hart, 1985). In some cases, it has been observed an effect of hydroclimatic variability and associated changes in turbidity, with lower densities during the rainy season, this is due to the effect of dilution and turbidity (López-López \& Serna-Hernández, 1999; Twombly, 1983; Hart, 1990; Arcifa, Gomez, \& Meschiatti, 1992; Vásquez \& Rey, 1992; Dejen, Vijverberg, Nagelkerke, \& Sibbing, 2004; Nogueira, Reis-Oliveira, \& Tenorio de Britto, 2008), but also from changes in stratification (Saunders \& Lewis, 1988; Mengestou \& Fernando, 1991; Panarelli, Nogueira, \& Henry, 2000); or changes in temperature, which also seem to correlate with changes in predation from Chaoborus and fishes in some cases (Cardoso \& Marques, 2009; JiménezContreras, Sarma, Merino-Ibarra, \& Nandini, 2009; Arcifa et al., 2015). In the present study, the temporal variation of zooplankton in a small neotropical lake, is examined in order to know if changes in zooplankton composition could be explained by the variation in the physical condition of the lake or by changes in phytoplankton composition.

\section{MATERIALS AND METHODS}

Study site and sampling: Fraijanes is a small lake located in the south west down slope of Poas Volcano, at $1160 \mathrm{~m}$ above the sea level. It has 2.2 ha of surface area and a maximum depth of $6.2 \mathrm{~m}$ when at its maximum level. It is eutrophic, and Secchi readings vary between 0.3 and $1.38 \mathrm{~m}$ (Umaña, 2014). The lake changes in water level with the season, and its outlet was active only during the rainy season, with a delay as the level dropped or accumulated back again. It remained dry from March until August 2009. Weather data was provided by the Field Station of the University of Costa Rica at Fraijanes (Station Number 84030, $\left.10^{\circ} 08^{\prime} 14.36^{\prime \prime} \mathrm{N}-84^{\circ} 11^{\prime} 36.58^{\prime \prime} \mathrm{W}\right)$. There was a marked dry season from December to April next year, and a minor dry period in July and August. Air temperature varied between 15 and $20{ }^{\circ} \mathrm{C}$, with minimum temperatures during January and February (Fig. 1).

Zooplankton was sampled at different times during a year period. It started in the middle of the rainy season in August, 2008 and extended into the rainy season in August, 2009. At the beginning sampling was weekly, but later it changed due to logistic reasons. Actual dates are shown in Table S1. A break in the sampling occurred between late December

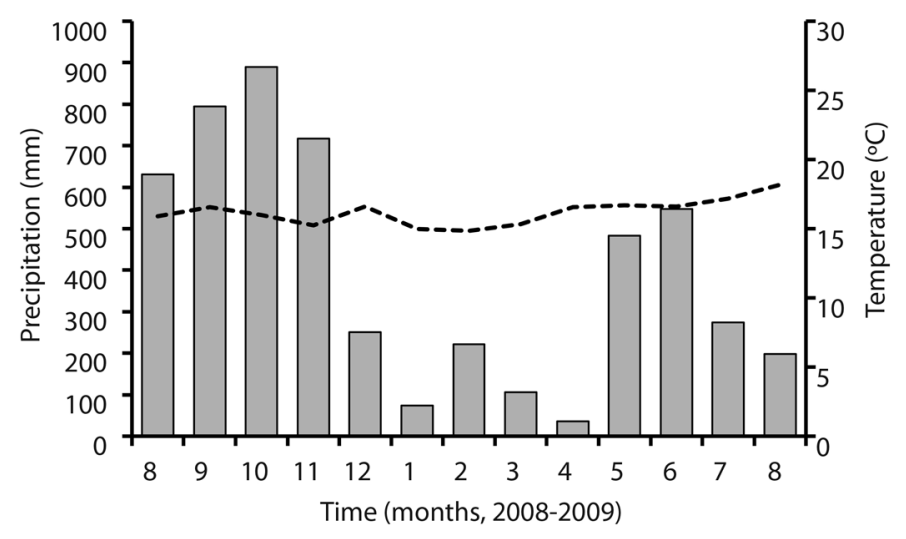

Fig. 1. Monthly variation of precipitation $(\mathrm{mm})$ and air temperature at a station near Lake Fraijanes (Station Number $84030,10^{\circ} 08^{\prime} 14.36^{\prime \prime} \mathrm{N}-84^{\circ} 11^{\prime} 36.58^{\prime}$ W). 
2008 and March 2009 due to the occurrence of an earthquake in January 2009, after which the recreational park where the lake is located, was closed to any visits as it was used as a temporal refuge. One sample was taken per visit, by a horizontal drag from a dock that reached into the middle of the lake, with a $64 \mu \mathrm{m}$ plankton net mesh size. The trawl distance was used to determine the density of organisms per liter. Samples were preserved in $4 \%$ formaldehyde, then the samples were washed with distillated water in the laboratory and preserved in $70 \%$ ethanol.

Quantification and identification: Samples analysis was made taking five aliquots of 1 $\mathrm{ml}$ per sample in which organisms were counted and identified. Zooplankton identification was made following the identification guides of Fernando (2002), Kotov \& Stifter (2006), Gutiérrez et al. (2008), Suárez-Morales, Reid, Iliffe \& Fiers (1996) y Maas (1998).

Statistical analysis: A cluster analysis was performed to test if changes in composition followed a seasonal trend. A correspondence analysis was employed as a mean to confirm the groupings of sampling dates along the year. A Similarity Percentage test (SIMPER) was used to determine which species contributed the most to the observed differences among periods of the year. An Analysis of Similarity (ANOSIM) was used to test whether the differences in composition among the periods of the year were significant. All analysis were performed using PAST software (Hammer, Harper, \& Ryan, 2001). Phytoplankton data composition from a parallel study (Umaña, 2014) was employed to test the relationship between zooplankton and phytoplankton by means of the BioEnv (Best Subset of Environmental Variables with Maximum (Rank) Correlation with Community Dissimilarities) (Clarke \& Ainsworth, 1993) of the library Vegan in $\mathrm{R}$ software. For this test phytoplankton data was considered as the environmental data that would explain zooplankton variation. Finally a Canonical Correspondence Analysis between both sets of data performed with PAST in order to visualize the relationships among the phytoplankton and zooplankton taxa.

\section{RESULTS}

A total of 59456 individuals were counted in all samples. From these, 12 taxa were identified, four of Cladocera, three of Copepoda, four of Rotifera and the larvae of Chaoborus (Table 1), however total diversity is higher

TABLE 1

List of species of zooplankton in Lake Fraijanes, with their accumulated total abundance and frequency of appearance. Groups marked with an asterisk are occasional occurrences of littoral dwellers

\begin{tabular}{llcc}
\multicolumn{1}{c}{ Taxonomic Group } & \multicolumn{1}{c}{ Species } & General Total & Frequency \\
Cladocera & Daphnia spp. & 5510.0 & 17 \\
& Ilyocryptus sp* & 289.1 & 2 \\
Copepoda & Paracyclops sp.* & 115.6 & 4 \\
& Thermocyclops sp. & 19919.4 & 17 \\
& Nauplio & 38722.9 & 17 \\
Rotifera & Brachionus sp & 333.0 & 3 \\
& Keratella cochleraris & 69.9 & 1 \\
& Keratella tropica & 6251.2 & 16 \\
Diptera & Lecane sp. & 802.2 & 7 \\
& Chaoborus sp. & 75.7 & 2 \\
Ostracoda & Other Diptera* & 125.4 & 4 \\
Tardigrada & Ostracoda* & 465.0 & 9 \\
\hline
\end{tabular}


since other groups such as an Ostracod and another Diptera larvae were observed but it was not possible to identify them due to their low abundance. The cladoceran Ilyocryptus, the copepod Paracyclops and ostracod were occasional dwellers of the pelagial. The most abundant group were the Copepods of the genus Thermocyclops sp., followed by the cladoceran Daphnia sp., Two species of Daphnia were observed: Daphnia laevis, which was the most abundant and Daphnia gessneri, with much lower density. Since it was not possible to identify each individual down to species level during sample enumeration, analysis of zooplankton variation was performed with the total Daphnia pooled together. Among the Rotifers, the most abundant species was Keratella tropica, followed by Brachionus sp. and Lecane sp.

Abundance of zooplankton changed along the year. During the rainy season 2008, when the outlet of the lake was active, abundance was low for most of the groups. During the dry season in 2009, density increased, especially due to an increase of Thermocyclops (Fig. 2).

The cluster analysis using Morisita Similarity Index, separated the sampling dates into three main groups, at the level of 0.81 similarity. A SIMPER analysis showed that $90 \%$ of the variation was explained by the relative dominance of Thermocyclops sp., Daphnia spp., and $K$. tropica (Fig. 3A). The first group included some of the samples from September to December 2008, and was characterized by the low abundance of all groups, and Daphnia was the second in importance. The second group included only the samples from March 2009, during the dry season with low water level, when the abundance of all groups was higher than the previous groups, and $K$. tropica was second in dominance over Daphnia sp. The third group included all other samples, some from 2008 and the samples of the rainy season of 2009, during which a high abundance of all groups, and Daphnia and K. tropica had similar abundances. An ANOSIM test yielded that the differences were highly significant different $(\mathrm{R}=0.8671 ; \mathrm{p}=0.0001)$. However, a Correspondence Analysis did not show such a clear separation between the periods of sampling (Fig. 3B), and the first and third groups did not separate much from each other.

The result of the BioEnv exploratory analysis using the phytoplankton composition as explanatory variables of the zooplankton yielded the best fit model with six phytoplankton taxa: Coelastrum proboscideum, Coelastrum reticulatum, Scenedesmus smithii,

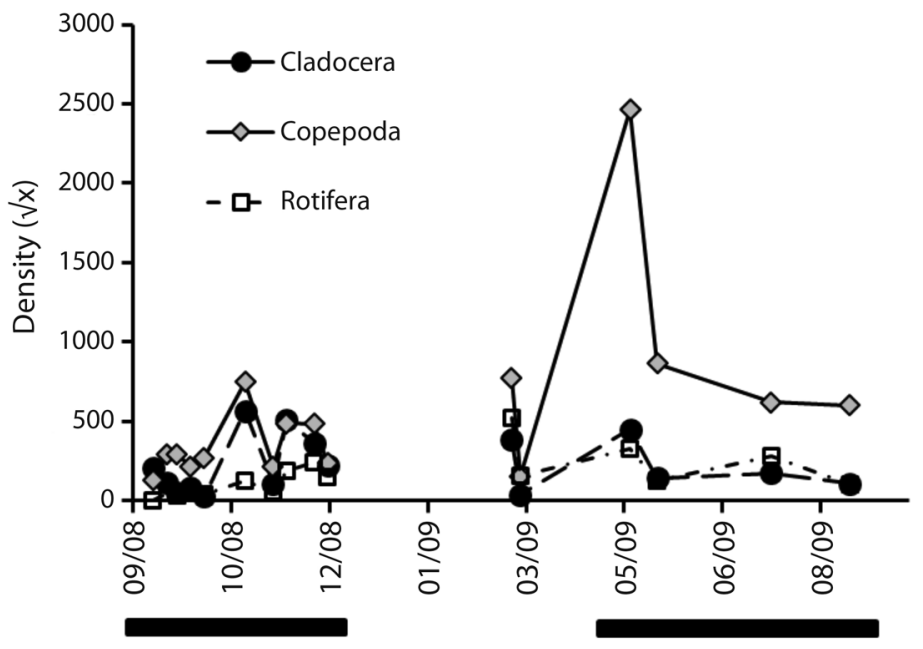

Fig. 2. Temporal variation of the main groups of the zooplankton assemblage in Lake Fraijanes 2008-2009. Densities are represented as the square root of actual values. Horizontal lines mark the extent of the rainy season. 
A

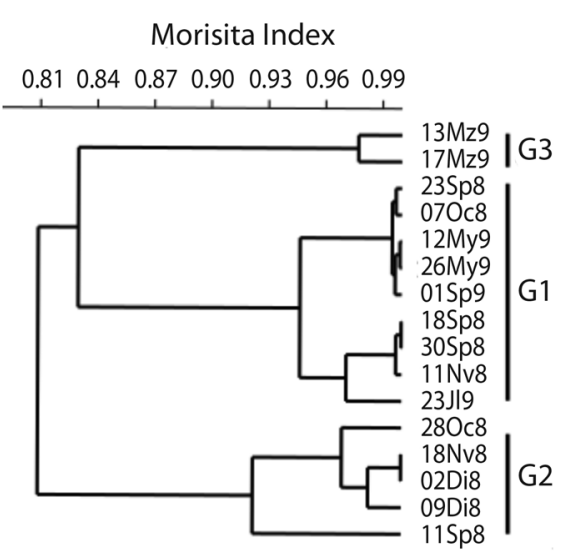

B

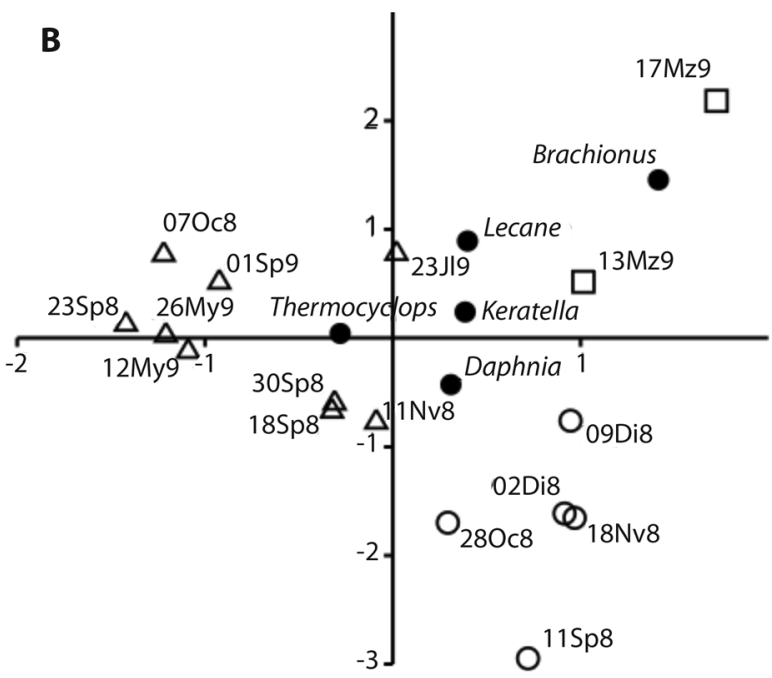

Fig. 3. A: Dendrogram of the sampling dates based on the abundance of the most common zooplankton taxa in Lake Fraijanes. Cophenetic correlation $=0.74 ; \mathbf{B}$ : Correspondence analysis of zooplankton among sampling dates in Lake Fraijanes. It also shows the relation of the taxa with both axis, to aid in the interpretation. Eigen values were $\lambda_{1}=0.1073$ (it explains $51 \%$ of the variation), $\lambda_{2}=0.0821(39 \%)$.

Cryptomonas ovata, Rhodomonas sp. and Cyclotella meneghiniana, in spite of the Spearman correlation between both sets of data that was low $(r=0.56)$. The canonical correspondence analysis including only the six best fitting phytoplankton species, showed that only Daphnia was most related with C. ovata and Rhodomonas. Cyclopoids were close to the center of the diagram and Keratella appeared off to the upper right, with little correlation with any of the phytoplankton taxa (Fig. 4)

\section{DISCUSSION}

Zooplankton composition in Lake Fraijanes has low species richness, such as most neotropical lakes in Central America (Collado, Defaye, Dussart, \& Fernando, 1984; Dussart, Fernando, Matsumura-Tundisi, \& Shiel, 1984). In previous work at the lake, four species of copepods were recorded (Collado et al., 1984), of which only Mesocyclops thermocyclopoides was later observed (Haberyan, Umaña, Collado, \& Horn, 1995). In this study a much richer fauna was recorded, including some Cladocera and Rotifera, and most abundant copepod species was Thermocyclops sp. Most species were observed only once during the study, and with low abundance.

Although two Daphnia species were identified there is still some controversy about whether these two species of Daphnia are

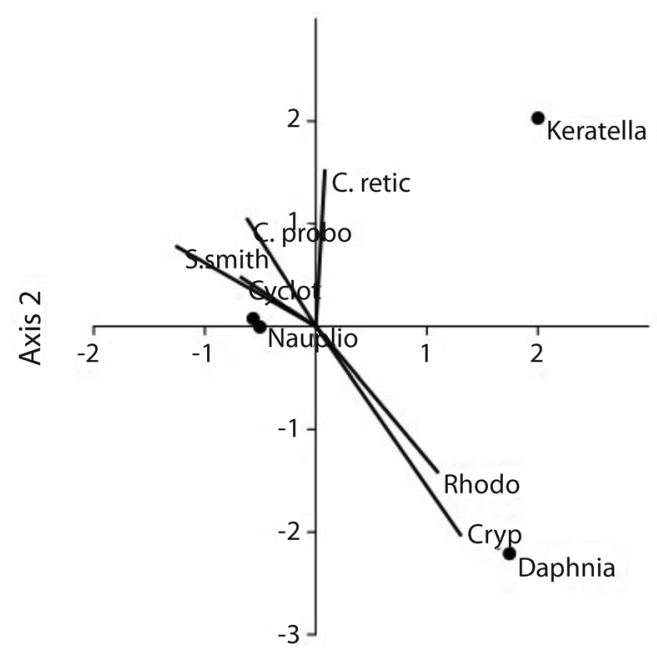

Axis 1

Fig. 4. Canonical correspondence analysis between selected phytoplankton species in Fraijanes lake and the most abundant zooplankton groups. Eigen values were $\Lambda_{1}$ $=0.2157(73.7 \%)$ and $\kappa_{2}=0.0760(26.0 \%)$. 
actually different forms of the same species or not (Fernando, Paggi, \& Rajapaksa, 1987; Taylor, Finston, \& Hebert, 1998). It is generally accepted that the genus Daphnia is less diverse in the tropics than it is in north temperate regions (Fernando et al., 1987; Dussart, 1994). These two species seldom occur simpatrically, and their co-occurrence in this small lake is interesting. The lake has been stocked with Tilapia fish for some time now, and although they are not supposed to feed on zooplankton, their presence might be influencing the occurrence of both $D$. laevis and D. gessneri. In fact, Arcifa \& Meschiatti (1996) report a case where $D$. gessneri was found in the diet of Tilapia in a Brazilian lake. A similar situation, where both species have been found together was reported from a Brazilian reservoir (PintoCoelho, Bezerra-Neto, \& Morais Jr., 2005) and in Itapeva Lake (Cardoso \& Marques, 2004).

The common genera of Rotifera (Keratella, Brachionus and Lecane) found in Fraijanes Lake are those typical of most shallow freshwater systems in the Neotropics (MiyashiroAoyagui \& Costa-Bonecker, 2004). Rotifers are generally the most speciose group in zooplankton community, but most species occur near the littoral (Bonecker \& Lansac-Tôha, 1996). Species richness of Rotifera is usually higher than the other zooplankton groups, as is the case in Fraijanes Lake, however the total number of taxa may be higher than was found in this small lake. In other lakes in Costa Rica, number of Rotifer species may be as high as 50, as was reported in Arenal Reservoir (Umaña \& Collado, 1990). In other cases in Costa Rica, Rotifer diversity has been also low, similar to Fraijanes. For example in Lake Cote a total of 12 species of Rotifers (Umaña, 2016; in prep.), and in Lake Río Cuarto Ramírez, Tabash, \& Charpentier (1990) reported the presence of five species of Rotifers.

Typically, eutrophic lakes are dominated by Rotifers, small sized Cladocera and Cyclopoid copepods (Pinto-Coelho et al., 2005; Merayo \& González, 2010), just as was the case in Fraijanes lake. However, instead of small sized species such as bosminids there were the two species of Daphnia, which seems off from what is expected from a small eutrophic lake. In other situations large Cladocera, mainly Daphnia are negatively affected by eutrophication due to interference with feeding apparatus caused by colonial and filamentous blue greens algae (Gliwicz, 2004). However in this lake, Daphnia species seem not to be affected by the composition of phytoplankton, given that it is dominated by green colonial and pico Cyanobacteria, and filamentous or big colonial phytoplankton species are scarce (Umaña, 2014). The lack of a close relationship between zooplankton and phytoplankton composition and abundance has also been observed in other cases, such as the Arenal Reservoir (Gavlas, 2012), and seems to support the hypothesis that the main food source for zooplankters are actually bacteria and suspended particulate organic matter (Pace, McManus, \& Findlay, 1990), since most phytoplankton species are inedible for the zooplankton considered as herbivores (Burns, 1968; DeMott, 1982). The presence of larvae of Chaoborus sp. is another factor that may influence the results, as it may be predating on smaller species such as rotifers and small Cladocera, which favors Daphnia. This agrees with the hypothesis proposed by Brooks \& Dodson (1965) about the effect of body size on the predation ecology of zooplankton.

The temporal variation followed a pattern of low abundance during the rainy season and high during the dry season. Although there was a gap in the sampling, it occurred during the transition from the rainy to the dry season, and as such, it was possible to compare the composition from both seasons. The difference between both seasons can be explained by the change in water level, since the outflow was active only during high level season. The outflow represents a source of mortality and wash out of plankton populations. This pattern of variation has been observed in other cases where the hydrological conditions change completely between dry and rainy season (Twombly, 1983; Hart, 1990; Arcifa et al., 1992; Vásquez \& Rey 1992; Dejen et al., 2004, Merayo \& González, 2010). But also changes 
in stratification, such as occur in Lake Fraijanes between wet and dry season (Umaña, 2014) are an important factor (Saunders \& Lewis, 1988; Mengestou \& Fernando, 1991; Panarelli et al., 2000) as this condition is highly associated with changes in weather conditions, as was also the case in Clavellinos reservoir (Merayo \& González, 2010).

In conclusion, composition and temporal variation of zooplankton community in Fraijanes lake, although is typical of a eutrophic lake, does not conform to the common view of trophic relationships between phytoplankton and zooplankton. The latter seems to respond more to variations in hydrological and environmental variables of the lake between wet and dry season; than to changes in phytoplankton composition.

\section{ACKNOWLEDGEMENTS}

This work was possible through the financial support of the Vice-rectory of Research of the Universidad de Costa Rica to the Center for Research on Marine Sciences and Limnology (CIMAR), Project number 808-A4-513. We are thankful to Juan Carlos Zuñiga, Sheila Castillo, Delia Zavala, Aldo Farah, and Anne Marie Gavlas who helped with field trips. Also to the administration of the INDER, and to Mr. Rafael Rojas Paniagua director of the Recreational Park of Fraijanes and the park personnel for their support and guarding of the buoy and sensors in the lake during the study.

\section{RESUMEN}

El zooplancton de lagos pequeños tropicales ha sido poco estudiado y sus variaciones a lo largo del año pueden responder a diferentes factores. En el presente estudio se analizaron los cambios de la comunidad zooplanctónica de un pequeño lago Neotropical en diferentes momentos durante un año y se compararon con cambios en las condiciones del lago y en la composición del fitoplancton. El lago se estratifica de marzo a septiembre y se mezcla durante el invierno hemisférico, de octubre a febrero. Además el lago muestra una fluctuación en el nivel del agua de acuerdo a la estacionalidad de las lluvias. El zooplancton estuvo compuesto por al menos 13 especies, cuatro Cladocera, tres Copepoda, cuatro Rotifera y otros grupos como
Ostracoda y larvas de Chaoborus. Las más abundantes fueron Thermocyclops sp., Daphnia sp. y Keratella tropica. Su abundancia fluctuó a lo largo del año, posiblemente en respuesta a cambios en el nivel del lago y cambios en las condiciones hidráulicas, con una mayor abundancia en la época seca, periodo durante el cual el efluente principal se secó. Los cambios en la composición del fitoplancton no parecen ser relevantes para la variación del zooplancton en este pequeño lago.

Palabras clave: Zooplancton, Neotropico, lagunas, estacionalidad.

\section{REFERENCES}

Arcifa, M. S., \& Meschiatti, A. J. (1996). Tilapia rendalli in the lake Monte Alegre, a case of planktivory. Acta Limnologica Brasiliensa, 8, 221-229.

Arcifa, M. S., Gomez, E. A. T., \& Meschiatti, A. J. (1992). Composition and fluctuations of the zooplankton of a tropical Brazilian reservoir. Archives für Hydrobiology, 123, 479-495.

Arcifa, M. S., dosSantos-Ferreira, T. C., Fileto, C., MaioliCastilho-Noll, M. S., Bunioto, T. C. \& Minto, W. J. (2015). A long-term study on crustacean plankton of a shallow tropical lake: the role of invertebrate predation. Journal of Limnology. Doi: 10.4081/ jlimnol.2015.1132.

Bonecker, C. C., \& Lansac-Tôha, F. A. (1996). Community structure of rotifers in two environments of the Upper Parana floodlain (MS) - Brazil. Hydrobiologia, 325, 137-150.

Brooks, J. L., \& Dodson, S. I. (1965). Predation, body size and composition of plankton. Science, 150, 331-340.

Burns, C. W. (1968). The relationship between body size of filter-feeding Cladocera and the maximum size of particle ingested. Limnology and Oceanography, 13(67), 678.

Cardoso, L. de J., \& Marques, D. da M. (2004). Structure of the zooplankton community in a subtropical shallow lake (Itapeva Lake - south of Brazil) and its relationship to hydrodynamic aspects. Hydrobiologia, 518, 123-134.

Cardoso, L. de J., \& Marques, D. da M. (2009). Hydrodynamics drives plankton community in a shallow lake. Aquatic Ecology, 43, 73-84.

Clarke, K. R., \& Ainsworth, M. (1993). A method of linking multivariate community structure to environmental variables. Marine Ecology Progress Series, 92, 205-219.

Collado, C., Defaye, D., Dussart, B. H., \& Fernando, C. H. (1984). The freshwater Copepoda (Crustaceae) of 
Costa Rica with notes on some species. Hydrobiologia, 119, 89-99.

De Groot, N. J. (1998). CATHALAC: a search for better understanding of the humid tropics of Latin America and the Caribbean. Hidrología en El Medio Tropical Húmedo, 253, 213.

Dejen, E., Vijverberg, J., Nagelkerke, L. A. J., \& Sibbing, F. A. (2004). Temporal and spatial distribution of microcrustacean zooplankton in relation to turbidity and other environmental factors in a large tropical lake (L. Tana, Ethiopia). Hydrobiologia, 513, 39-49.

DeMott, W. R. (1982). Feeding selectivities and relative ingestion rates of Daphnia and Bosmina. Limnology and Oceanography, 27(3), 518-527.

Dussart, H. J. (1994). On the diversity of Cladocera in the tropics. Hydrobiologia, 272, 27-38.

Dussart, B. H., Fernando, C. H., Matsumura-Tundisi, T., \& Shiel, R. J. (1984). A review of systematics, distribution and ecology of tropical freshwater zooplankton. Hydrobiologia, 113, 77-91.

Fernando, C. H. (2002). A guide to tropical freshwater zooplankton. Identification, ecology and impact on fisheries. Netherlands: Backhuys Publishers. Leiden.

Fernando, C. H., Paggi, J. C., \& Rajapaksa, R. (1987). Daphnia in tropical lowlands. In R. H. Peters, \& R. De Bernardi (Eds.). Daphnia (pp. 107-141). Verbania Pallanza, Italy: Memorie dell'Instituto Iatliano di Idrobiologia Dott. Marco de Marchi.

Gavlas, A. (2012). Cambios estacionales y relaciones alimentarias de la comunidad planctónica del embalse arenal, Costa Rica (Tesis de Maestría). San José, Costa Rica: Universidad de Costa Rica.

Gliwicz, Z. M. (2004). Zooplankton. In P. E. O’Sullivan, \& C. S. Reynolds (Eds.). The lakes Handbook: Limnology and limnetic ecology (pp. 461-516). Oxford, U. K.: Blackwell Publishing.

Gutiérrez, M. L., Suárez-Morales, E., Gutiérrez-Aguirre, M. A., Silva-Briano, M., Granados-Ramírez, J. G., \& Garfias-Espejo, T. (2008). Cladocera y Copepoda de las aguas continentales de Mexico. Guía ilustrada. México: Sermanat.

Haberyan, K. A., Umaña, G., Collado, C., \& Horn, S. (1995). Observations on the plankton of some Costa Rican lakes. Hydrobiologia, 312, 75-85.

Hammer, Ø., Harper, D.A.T., \& Ryan, P. D. (2001). PAST: Paleontological statistics software package for education and data analysis. Palaeontologia Electronica, 4(1), 9. Retrieved from http://palaeo-electronica. org/2001 1/past/issue1 01.htm
Hart, R. C. (1985). Seasonality of aquatic invertebrates in low-latitude and Southern Hemisphere inland waters Hydrobiologia, 93, 194-208.

Hart, R. C. (1990) Zooplankton distribution in relation to turbidity ad related environmental gradients in a large subtropical reservoir: patterns and implications Freshwater Biology, 24, 241-263.

Haug, G. H., Hughen, K. A., Sigman, D. M., Peterson, L. C., \& Röhl, U. (2001). Southward migration of the intertropical convergence zone through the Holocene. Science, 293(5533), 1304-1308.

Hutchinson, G. E., \& Löffler, H. (1956). The thermal classification of lakes. Proceedings of the National Academy of Sciences, 42(2), 84-86.

Jiménez-Contreras, J., Sarma, S. S. S., Merino-Ibarra, M., \& Nandini, S. (2009). Seasonal changes in the rotifer (Rotifera) diversity from a tropical high altitude reservoir (Valle del Bravo, Mexico). Journal of Environmental Biology, 30, 191-195.

Kotov, A. A., \& Štifter, P. (2006). Cladocera. Family Ilyocryptidae (Branchiopoda, Cladocera, Anomopoda). Ghent, Belgium: Kenobi Productions, and Leiden, The Netherlands: Backhuys Publishers.

Kricher, J. (2011). Tropical ecology. New Jersey, USA: Princenton University Press.

Lewis, W. M., Jr. (1996). Tropical lakes: how latitude makes a difference. In F. Schiemer \& K.T. Boland (Eds.). Perspectives in tropical limnology (pp. 43-64). Amsterdam, The Netherlands: SPB Academic Publishing.

López-López, E., \& Serna-Hernández, J. A. (1999). Variación estacional del zooplancton del embalse Ignacio Allende, Guanajuato, México y su relación con el fitoplancton y factores ambientales. Revista de Biología Tropical, 47(4), 643-657.

Maas, S. (1998) Introduction to the identification of Copepoda (Calanoida \& Cyclopoida). International Training Course 'Lake zooplankton: a tool in Lake Management'. Gent, Belgium: Laboratorium Voor Ecologie der Dieren, Universiteit Gent.

Mengestou, S., \& Fernando, C. H. (1991). Seasonality and abundance of some dominant crustacean zooplankton in Lake Awasa, a tropical Rift Valley in Ethiopia. Hydrobiologia, 266, 137-152.

Merayo, S., \& González, E. J. (2010). Variaciones de abundancia y biomasa del zooplancton en un embalse tropical oligo-mesotrófico del norte de Venezuela. Revista de Biología Tropical, 58(2), 603-619.

Miyashiro-Aoyagui, A. S., \& Costa-Bonecker, C. (2004). The art status of rotifer studies in natural environments of South America: floodplains. Acta Scientiarum Biological Sciences Maringá, 26, 385-406. 
Nogueira, M. G., Reis-Oliveira, P. C., \& Tenorio de Britto, Y. (2008). Zooplankton assemblages (Copepoda and Cladocera) in a cascade of reservoirs of a large tropical river (SE Brazil). Limnetica, 27(1), 151-170.

Pace, M. L., McManus, G. B., \& Findlay, S. E. G. (1990). Planktonic community structure determines the fate of bacterial production in a temperate lake. Limnology and Oceanography, 35, 795-808.

Panarelli, E. A., Nogueira, M. G., \& Henry, R. (2000). Short term variability of copepod abundance in Jurumirim Reservoir, Sao Paulo. Brazil. Brazilian Journal of Biology, 61, 577-598.

Pinto-Coelho, R. M., Bezerra-Neto, J. F., \& Morais-Jr, C. A. (2005). Effects of eutrophication on size and biomass of crustacean zooplankton in a tropical reservoir. Brazilian Journal of Biology, 65, 325-338.

Ramírez, E., Tabash, F., \& Charpentier, C. (1990). Variación estacional en el lago de Río Cuarto, Provincia de Alajuela, Costa Rica. II. Distribución estacional del zooplancton. Uniciencia, 7, 19-25.

Roldán-Pérez, G., \& Ramírez-Restrepo, J. J. (2008). Fundamentos de limnología neotropical. Medellín, Colombia: Editorial Universidad de Antioquia.

Saunders, J. F., \& Lewis, W. M. (1988). Dynamics and control mechanisms in a tropical zooplankton community (Lake Valencia, Venezuela). Ecological Monographs, 58, 337-353.

Sommer, U. Z., Gliwicz, M., Lampert, W., \& Duncan, A. (1986). The PEG-model of seasonal succession of phytoplanktonic events in fresh waters. Archiv für Hydrobiologie, 106, 433-471.

Sommer, U., Adrian, R., De Senerpont Domis, L., Elser, J. J., Gaedke, U., Ibelings, B., ... Winder, M. (2012). Beyond the plankton ecology group (PEG) model: mechanisms driving plankton succession. Annual Review of Ecology and Systematics, 43, 429-448. DOI: 10.1146/annurevecolsys-110411-160251.

Suárez-Morales, E., Reid, J. W., Iliffe, T. M., \& Fiers, F. (1996). Catálogo de los copépodos (Crustacea) continentales de la Peínsula de Yucatán, México. Quintana Ro, Mexico: El Colegio de la Frontera Sur.

Taylor, D. J., Finston, T. L., \& Hebert, P. D. N. (1998). Biogeography of a widespread freshwater crustacean: pseudocongruence and cryptic endemism in the North American Daphnia laevis complex. Evolution, $52,1648-1670$.

Twombly, S. (1983). Seasonal and short term fluctuations in zooplankton abundance in tropical lake Malawi. Limnology and Oceanography, 28, 1214-1224.

Umaña, G. (2016). Monitoreo limnológico del Lago Cote. Segundo informe para la Compañía Nacional de Fuerza y Luz. San José, Costa Rica: CIMAR, Universidad de Costa Rica.

Umaña, G. (2014). Phytoplankton variability in Lake Fraijanes, Costa Rica, in response to local weather variation. Revista de Biología Tropical, 62, 483-494.

Umaña, G., \& Collado, C. (1990). Asociación plantónica en el Embalse Arenal, Costa Rica. Revista de Biología Tropical, 38(2A), 311-321.

Vásquez, E., \& Rey, J. (1992). Composition, abundance and biomass of zooplankton in Orinoco floodplain lakes, Venezuela. Annals of Limnology, 28, 3-18.

Waylen, P., Caviedes, C., Poveda, G., Mesa, O., \& Quesada, M. (1998). Rainfall distribution and regime in Costa Rica and its response to the El Nino-Southern Oscillation. Yearbook (Conference of Latin Americanist Geographers), 24, 75-84. 